\title{
WEB USABILITY EVALUATION TO PROMOTE PUBLIC RESPONSIBILITY FOR MUNICIPAL WASTE AND RESOURCE-EFFICIENCY
}

\author{
Norin Sultana \\ School of business and economics, Linnaeus University, Kalmar, Sweden \\ Muhammad Asim Ibrahim \\ School of natural sciences, Linnaeus University, Sweden \\ William Hogland \\ School of natural sciences, Linnaeus University, Sweden
}

\begin{abstract}
The main elements of any communication process are source, message and recipient. In order to promote public responsibility for municipal solid waste and resource efficiency, national municipal waste management (MWM) association being reputed and trustworthy source of information could play a central role to educate recipients (general public). The internet technology can be employed as an effective source for mentoring due to its; tremendous growth rate, popularity, cost effectiveness and flexibility to divulge information in multiple forms such as videos, blogs, pictures etc. In this study websites of 4 national MWM associations of Nordic countries were studied. These associations were member of Municipal Waste Europe (MWE), a non-profit organization with prime objective to promote public responsibility for resource efficiency.

The purpose of the study was to perform the real time scenario-based usability testing of the above mentioned website, especially for the Nordic countries in order to determine the ease with which people are able to find the information on these websites.

The features of National MWM association of Finland, to promote public responsibility, were found to be most promising compared to that of other Nordic MWM organization. The study has also highlighted promising examples of use of the internet technology employed by various MWM associations that others can follow to develop sustainable societies.
\end{abstract}

\section{KEYWORDS}

Municipal Waste Management, Public Awareness, Resource efficiency, Source Separation, WebUsability 


\section{INTRODUCTION}

The article 18 of EU council directive 2008/98/EC has urged the source separation of priority waste streams. However, it is found that in some European countries such as United Kingdom and France, source separation of household waste is not promoted [1]. The Spain is an example where source separation of paper/cardboard and light weight packaging is still below that of regulatory demands [2] and in Greenland it is quite common that people mix household with hazardous waste such as batteries, leftover paint, nail polish or other chemicals and only $25 \%$ reached to recycling stations [3]. The 70 municipalities in Sweden are still planning to implement source separation of household waste [4]. Furthermore, in Sweden national targets of source separation of newspaper and plastic packaging are not matched with the associated environmental benefits of per ton of material recycled [5]. This suggests that there is a lot of potential to improve the public responsibility for municipal solid waste (MSW) and resource efficiency in European society.

Apart from resource efficiency, source separation can help in reducing the risk of spontaneous fires. It is know that presence of metallic fractions catalyzes the biological respiration and can sharply increases the risk of spontaneous fires [6, 7]. It is important to note that the environmental impact of a single fire could be higher than the total annual emissions from all incineration plants in Sweden [8]. In addition to it incorrectly sorted material (having batteries or paints in ordinary waste) on being incinerated release toxic emissions. The enhancement of public responsibility for source separation of MSW would help in improving the resource efficiency and diminishing the risk of fires at landfills and preliminary storage sites of MSW.

The internet could be an effective medium of promoting public responsibility being having less capital involvement, possibility of wide spread of information and have multiple possibilities to attract people such as by videos, animations, blog and open forms [9]. The internet as a medium of communication has been successfully employed to improve standards; of higher education [10], health [11] and motivating people in political campaigns [12]. Similarly this technology can be used to change the behavior of people towards apposite source separation of MSW, due to its growing use. There are about $73 \%$ of households in EU-27 have internet access which is a $24 \%$ increase since 2006 [13]. Furthermore, with the technical advancements in the field of information and communication technologies (ICT's) the word of internet has been stretched from desktop PC's to hand held devices such as; smartphone, tablet computer, IPhones, and notepads. The access to handheld devices and mobile broadband has brought new opportunities for people to spend even more time on internet such as during travelling, shopping, cooking, lying in bed or camping etc. which was not possible ever before. Furthermore, data trafficking through mobile broadband is expected to be get double every year until 2014 [14]. Due to high expectations of internet users to be connected round the clock with their peers/costumers/ clients and in order to have an access to information at anytime, anywhere and on any device have made it extremely important to develop websites that would be equally accessible on mobile browsers. Not only in Europe but all over the world, governmental, non-governmental as well as private organizations have developed their websites to help public/costumers to get quick and easy access to information. Furthermore, the social media has become an essential component of modern websites due it's increased use in past one decade. Unlike television and press media, websites and social media have the provision to provide direct two way communication and 
ensure connectivity with higher trust. The most effective forum to improve public responsibility for source separation of MSW could be the websites of national waste management associations.

In the sector of waste management, most of the European countries have developed national waste management associations that act as central expert authorities in the subject area and help in national policy making for sustainable waste management and to disseminate information in general. These national associations also collaborate with each other at different forums such as Municipal Waste Europe (MWE) is a European forum while International Solid Waste Association (ISWA) is an international forum for cooperation. The MWE is a non-profit European association with a prime objective to promote public responsibility for municipal waste management in Europe [15]. Currently MWE has 14 member countries represented by 14 MWM associations (see Table-1). These members serve $45 \%$ of European population (EU$27+$ Norway+Iceland+Switzerland+Liechtenstein). Keeping in view the changing trends in the use of ICT's, it is rationale to connect degree of success in increasing the public responsibility for source separation of MSW with that of quality of web sites of MWM associations. A websites must comply with current EU standards known as web content accessibility guidelines-2.0 (WCAG 2.0) and must be perceivable, operable, understandable and robust [16]. The objective of the study is to evaluate:

1. The usability of websites of 4 Nordic members of MWE and;

2. General features such use of web 2.0 and language for all of the 14 members of MWE as listed in Table 1

\begin{tabular}{|l|l|l|}
\hline Name & Country & Web-Address \\
\hline Avfall Sverige & Sweden & $\underline{\text { www.avfallsverige.se }}$ \\
\hline Renosam & Denmark & www.renosam.dk \\
\hline Jätelaitosyhdistys-JLY & Finland & www.jly.fi \\
\hline Avfall Norge & Norway & $\underline{\text { www.avfallnorge.no }}$ \\
\hline Austrian association of cities and Town & Austria & www.staedtebund.gv.at \\
\hline Interafval & Belgium & www.interafval.be \\
\hline Amorce & France & www.amorce.asso.fr \\
\hline VKU & Germany & www.vku.de \\
\hline DiFoDiSA & Greece & www.dyfodisa.gr \\
\hline Association of Local Authorities in Iceland & Iceland & www.samband.is \\
\hline Federambiente & Italy & www.federambiente.it \\
\hline NVRD & Netherlands & www.nvrd.nl \\
\hline EGSRA & Portugal & $\underline{\text { www.egsra.pt }}$ \\
\hline LARAC & United Kingdom & www.larac.org.uk \\
\hline
\end{tabular}

Table 1: National waste management association of European countries that are member of Municipal Waste Europe

The results of the study would help to know the current state of quality of websites of national MWM associations at first place and then help to improve the design of websites with a special focus to enhance the public responsibility for MWM, to improve resource efficiency and to decrease risk of spontaneous fires. This study is a one step towards efficient use of current ICT's 
to persuade people from all walks of life in order to make dream come true of sustainable societies.

\section{METHOD}

The usability test sessions were conducted in accordance with the guidelines of [17].Three users groups were identified; 1). Common person from society; 2). Researchers; and 3). Waste management companies, which can visit websites of national waste management associations. Three scenarios were designed based on three types of potential visitors and details are shown in Table-2. The recruiters of the usability test were asked to perform the relevant tasks based on three scenarios and requested to think aloud. The recruiters were not allowed to use the search option on the web page. The performance was accessed in terms of completion time of tasks and also on success/failure to complete the tasks. Four sessions were conducted with each evaluator and each session followed by a post user testing questionnaire. In posttest questionnaire evaluators were asked to list three usability problems faced during the test session and to rank the web site on a scale of 1 to 5 based on different aspects such as; contents, color scheme, images, animation/videos, layout, organization and structure of information.

In this study four participants were recruited, as 3-5 participants are believed to be enough to identify most of the usability problems of any website and recruitment of higher number of participants do not help in identifying more problems [17]. Among the four recruits in this study, two were "double expert" and two were "single expert". The "double expert" means a person with basic understanding of usability issues and has worked in the relevant subject area [18]. Among the two double experts recruited in this study, one is working as a project coordinator in the Environmental Science and Engineering Group (ESEG) at Linnaeus University while the second is a Post Doc researcher and spent most of the time on internet while visiting webpages of different authorities. The two double experts employed in the study, on average spent more than $30 \& 15$ hours per week respectively and have sufficient understanding of usability issues. The "single experts" recruited in this study were administrators at School of Natural Sciences at Linnaeus University, while one of the administrators had also worked as a librarian and have expertise of 7 different international languages. The single experts employed in this study, on average spent more than $60 \& 30$ hours per week respectively and have sufficient knowledge of usability issues.

The web usability tests were conducted for MWM associations of Nordic countries only. The Nordic countries were chosen as being exemplary due to their achievement in the field of waste management in the whole world and the knowledge obtained from the usability tests can be considered as a touch stone to compare the quality of websites of MWM associations working at other parts of the world. 


\begin{tabular}{|c|c|}
\hline Scenarios & Task List \\
\hline $\begin{array}{l}\text { Scenario-1 (5-minutes): } \\
\text { You are a common person from society and eager to } \\
\text { update yourself with the current activities and trends in } \\
\text { the field of waste management in order to explain it to } \\
\text { your kids/peers/siblings. You need to find current } \\
\text { statistics regarding municipal solid waste for the year } \\
2011 \text {; }\end{array}$ & $\begin{array}{l}\text { Find information about total municipal waste generated; } \\
\text { Find information about total waste incinerated; } \\
\text { Find information about total waste composted and } \\
\text { digested; } \\
\text { Find information about total waste landfilled; }\end{array}$ \\
\hline $\begin{array}{l}\text { Scenario-2 (5-minutes): } \\
\text { You are a researcher and want to get detail information } \\
\text { regarding waste-energy sector. }\end{array}$ & $\begin{array}{l}\text { Find information about incineration plants; } \\
\text { Find names of members of waste association; }\end{array}$ \\
\hline $\begin{array}{l}\text { Scenario-3 (5-minutes): } \\
\text { You are running a waste management company and want } \\
\text { to be a member of national waste management } \\
\text { association. }\end{array}$ & $\begin{array}{l}\text { What are the requirements to be qualify as a member for } \\
\text { national waste association? } \\
\text { What benefits would you gain on being a member? }\end{array}$ \\
\hline
\end{tabular}

\section{Table 2 : Scenarios and task list for usability testing}

\section{RESULTS}

\subsection{Web usability}

A number of non-overlapping quality features have been found on the websites of MWM associations of Nordic countries. The success rate for scenario-1 was 100\% for Swedish website while it turns out to be a complete failure for Danish website. The annual report regarding statistics of waste was easily accessible on Swedish website while Danish report was hard to find as well as difficult to extract waste statistics out of it. On the other for Senario-2, Danish and Finish websites got higher success rate in compare to Swedish and Norwegian website. Both Danish and Finish websites have made a digital map of location of members of national waste associations' which facilitated visitors to extract the information, while Swedish and Norwegian sites did not develop such digital maps. Based on the comments of the recruiters of the usability test, Table-3 summarizes the details of general usability problems and positive features of each website. These comments in future can be helpful to upgrade the websites of MWM associations. Finish website was found to be most highly rated by the participants of the study in compare to any other website.

The results of mobile accessibility show that beside national MWM association of Germany none of the member associations of MWE has developed mobile version of websites. It is strongly recommended to other MWM associations to develop mobile version of their websites following the example of German MWM association.

\subsection{Web 2.0}

Based on the statistics of year 2010, altogether 14 members of MWE represent 233.01 million people (i.e. $67 \%$ of the total populations of 14 member countries of MWE) [15]. Among the 14 
members of MWE, MWM associations of only 5 countries (Sweden, Austria, Germany, Portugal and Netherland) are using social media to get connected with the people. These five countries represent only $28.57 \%$ (66.58 million people) of the total population represented by the members of MWE (233.01 million people) as shown in Figure-1. It is concluded that national MWM associations that represent a higher proportion of population in Europe are still not taking advantage of advanced communication tools riffed in our today's society.

\subsection{Language}

The MWM associations of only 5 countries (Sweden, Denmark, Finland, Germany and Austria) have established at least one page in English. The MWM association of Finland has provided option of two additional languages, Swedish and English, on their website beside native language. Similarly website of MWM association of Germany has also provided the option of two additional languages, French and English, to read the reports. The language as a barrier limits a visitor of website from being getting an access to information. It is recommended that beside native language websites must have provision to see the contents in English as being an international language.

\section{RECOMMENDATIONS}

Following are some recommendation to enhance the public responsibility for MSW and resource efficiency:

1. The current Swedish national web accessibility guidelines for public sector websites recommend WCAG 1.0 [19] and should follow WCAG 2.0 which EU has considered as a standard. This may also act as a driving force to improve the accessibility of websites.

2. Web 2.0 can be employed to promote public responsibility for MSW and resource efficiency.

3. Nowadays products are labeled with Neotags (2D bar codes) for promotion of products on websites. These tools can be used to enhance the public responsibility for source separation by making information accessible to people on web.

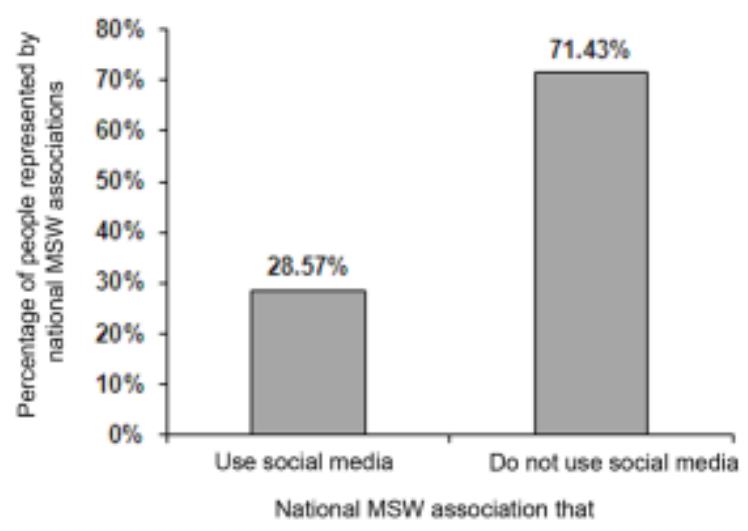

Figure 1: National MWM associations that either use or do not use social media and percentage of population represented by these MWM associations 


\begin{tabular}{|c|c|c|}
\hline Website & Positive aspects & Usability Problems \\
\hline $\begin{array}{l}\text { Sweden } \\
\text { (www.avfallsverige.se) }\end{array}$ & $\begin{array}{l}\text { A page for English speakers } \\
\text { An easy access to Annual report } \\
\text { and basic statistics } \\
\text { Use of social media (Facebook and } \\
\text { Twitter) }\end{array}$ & $\begin{array}{l}\text { To much information on first page } \\
\text { First impression is that it would be difficult } \\
\text { to find any information out of this website. } \\
\text { Almost all text is of same size } \\
\text { No animation/videos }\end{array}$ \\
\hline $\begin{array}{l}\text { Denmark } \\
\text { (www.renosam.dk) }\end{array}$ & $\begin{array}{l}\text { A page for English speakers } \\
\text { A clickable map of members of } \\
\text { association } \\
\text { Good pictures to describe purpose } \\
\text { of website }\end{array}$ & $\begin{array}{l}\text { No "Contact us" button on top } \\
\text { Very small text } \\
\text { Text scrolling at a fast rate } \\
\text { To much emphasis on news } \\
\text { No animation/videos } \\
\text { No use of social media }\end{array}$ \\
\hline $\begin{array}{l}\text { Finland } \\
\text { (www.jly.fi) }\end{array}$ & $\begin{array}{l}\text { Option for two languages (Swedish } \\
\text { and English) beside Finish } \\
\text { A clickable map of members of } \\
\text { association } \\
\text { Good color scheme } \\
\text { Animation on website to promote } \\
\text { public responsibility for source } \\
\text { separation }\end{array}$ & $\begin{array}{l}\text { Small text } \\
\text { Folder navigation } \\
\text { No use of social media }\end{array}$ \\
\hline $\begin{array}{l}\text { Norway } \\
\text { (www.avfallsnorge.no) }\end{array}$ & $\begin{array}{l}\text { A very well described purpose of } \\
\text { website } \\
\text { Very good text size } \\
\text { Not text heavy }\end{array}$ & $\begin{array}{l}\text { No pictures at all } \\
\text { External links to get basic statistics } \\
\text { No side bars and all the links are placed at } \\
\text { the bottom of web page } \\
\text { No language option other than Norwegian } \\
\text { No use of social media }\end{array}$ \\
\hline
\end{tabular}

Table 3: Usability test outcomes for websites of MWM associations of Nordic countries

4. The computer games based on recycling can be another source to educate people;

5. The digitals maps of recycling stations can be placed on home page of MWM association to facilitate people to answer question such as "where should I dispose my waste?";

6. The adaptable websites can be developed to facilitate the people with visual impairment;

\section{REFERENCES}

[1]. Baere, L, D and Mattheeuws, B., 2010. Anaerobic digestion of MSW in Europe, Biocycle, Vol. 51, No. 2, p. 24. Available on: (http://www.resol.com.br/textos/anaerobic_digestion_of_msw_in_europe.html) [12-09-2012]. [2]. Gallardo, A., Bovea, M, D., Colomer, F, J., Prades, M., Carlos, M., 2010. Comparison of different collection systems for sorted household waste in spain, Waste Management, 30(12), 2430-2439

[3]. EEA, 2011. Video: Mission Greenland for a cleaner future, European Environmental Agency, Available on: http://www.eea.europa.eu/atlas/eea/mission-greenland/video/video-file/view [25-09-2012] [4]. Wiqvist, W., 2011. Swedish waste management-2011. Avfall Sverige, Malmö, Sweden 
[5]. Bernstad, A., Jansen, Jes-la, C., Aspegren, H., 2011. Life cycle assessment of a household solid waste source separation programme: a Swedish case study, Waste Management and Research, 29(10), 1027-1042

[6]. Hogland, W., and Marques, M, 2007 Fires in storage areas for organic waste, Proceedings of the international conference on sustainable solid waste management, 5-7 September 2007, Chennai, Indea, PP-189-196

[7]. Hogland, W., Bramryd, T., Persson, I., 1996. Physical, biological and chemical effects of unsorted fractions of industrial solid waste in waste fuel storage, Waste Management and Research, 14(2), 197-210

[8]. Stenis, J., Moutavtchi, V., Hogland, W., 2011. Solid waste management baling scheme economics methodology, Iranica Journal of Energy and Environment, 2(2), 104-116

[9]. Feng-ling, B., 2010. Analysis on media's responsibilities for public fire safety, The prodeedings of 2010 international conference on public administration $\left(6^{\text {th }}\right)$, October 22-24, 2010, Canberra, Australia, ISBN, 9787564706241

[10]. Bennett, S., Bishop, A., Dalgarno, B., Waycott, J., Kennedy, G., 2012. Implementing web 2.0 technologies in higher education: A collective case study, Computers \& Education, Vol.59(2), $524-534$

[11]. Mayer., A, B., Harrison, J, A., 2012. Safe Eats: An evaluation of the use of social media for food safety education, Journal of Food Protection, vol. 75(8) 1453-1463

[12]. Larsson, A, O., Moe, H., 2012, Studying political microblogging: Twitter users in the 2010 Swedish election campaign, New Media and Society, 14(5), 729-747nomics, 39(4) 621-627

[13]. Eurostat., 2011. Europe in Figures: Eurostat yearbook 2011, European Commission, ISBN 978-92-79-18414-7

[14]. Domingue, J., Galis, A., Gavras, A., Zahariadis, T., Lambert, D., Cleary, F., Daras, P., Krco, S., Muller, H., Li, M., Schaffers, H., Lotz, V., Alvarez, F., Stiller, B., Karanouskos, S., Avessta, S., Nilsson, M., 2011. The Future Internet-Future internet assembly 2011: Achievements and technological promises, Springer, ISBN 978-3-642-20897-3

[15]. MWE., 2012. (Municipal Waste Europe: Promoting public responsibility for waste, Available on: http://www.municipalwasteeurope.eu/ [14-09-2012]

[16]. EC, 2011. The EU internet handbook:Information providers guide, Available on: http://ec.europa.eu/ipg/standards/accessibility/wcag-20/standard_wcag_en.htm [15-09-2012]

[17]. Krug, 2010. Rocket surgery made easy: The do it yourself guide to finding and fixing usability problems, $2^{\text {nd }}$ Edition, pp. 168

[18]. Tan, W, S., Liu, D, H., Bishu, R., 2009. Web evaluation: Heuristic evaluation vs. user testing, International Journal of Industrial Ego

[19]. VERVA, 2008. Swedish national guidelines for public sector websites, Swedish Administrative Development Agency, Editor: Magnus Burell, 